\title{
Galanin receptors in GtoPdb v.2021.3
}

\author{
Andrew L. Gundlach ${ }^{1}$ and Philip J. Ryan ${ }^{1}$
}

1. University of Melbourne, Australia

\begin{abstract}
Galanin receptors (provisional nomenclature as recommended by NC-IUPHAR [57]) are activated by the endogenous peptides galanin and galanin-like peptide. Human galanin is a 30 aminoacid non-amidated peptide [52]; in other species, it is 29 amino acids long and C-terminally amidated. Amino acids 1-14 of galanin are highly conserved in mammals, birds, reptiles, amphibia and fish. Shorter peptide species (e.g. human galanin-1-19 [21] and porcine galanin-5-29 [170]) and Nterminally extended forms (e.g. N-terminally seven and nine residue elongated forms of porcine galanin $[22,170]$ ) have been reported. More recently, the newly-identified peptide, spexin (SPX), has been reported to activate human GAL2 and GAL3 (but not GAL1) receptors in heterologous expression systems; and to alter GAL2/3 receptor-related behaviours in animals [89].
\end{abstract}

\section{Contents}

This is a citation summary for Galanin receptors in the Guide to Pharmacology database (GtoPdb). It exists purely as an adjunct to the database to facilitate the recognition of citations to and from the database by citation analyzers. Readers will almost certainly want to visit the relevant sections of the database which are given here under database links.

GtoPdb is an expert-driven guide to pharmacological targets and the substances that act on them. GtoPdb is a reference work which is most usefully represented as an on-line database. As in any publication this work should be appropriately cited, and the papers it cites should also be recognized. This document provides a citation for the relevant parts of the database, and also provides a reference list for the research cited by those parts. For further details see [31].

Please note that the database version for the citations given in GtoPdb are to the most recent preceding version in which the family or its subfamilies and targets were substantially changed. The links below are to the current version. If you need to consult the cited version, rather than the most recent version, please contact the GtoPdb curators.

\section{Database links}

Galanin receptors

https://www.guidetopharmacology.org/GRAC/FamilyDisplayForward?familyId=27

Introduction to Galanin receptors

https://www.guidetopharmacology.org/GRAC/FamilyIntroductionForward?familyId=27

Receptors

$\mathrm{GAL}_{1}$ receptor

https://www.guidetopharmacology.org/GRAC/ObjectDisplayForward?objectId=243

$\mathrm{GAL}_{2}$ receptor

https://www.guidetopharmacology.org/GRAC/ObjectDisplayForward?objectId=244

$\mathrm{GAL}_{3}$ receptor

https://www.guidetopharmacology.org/GRAC/ObjectDisplayForward?objectId=245

\section{References}

1. Alier KA, Chen Y, Sollenberg UE, Langel U and Smith PA. (2008) Selective stimulation of GalR1 and GalR2 in rat substantia gelatinosa reveals a cellular basis for the anti- and pro-nociceptive actions of galanin. Pain 137: 138-46 [PMID:17910903] 
2. Anderson ME, Runesson J, Saar I, Langel U and Robinson JK. (2013) Galanin, through GalR1 but not GalR2 receptors, decreases motivation at times of high appetitive behavior. Behav Brain Res 239: 90-3 [PMID:23142608]

3. Anisimov SV, Tarasov KV, Tweedie D, Stern MD, Wobus AM and Boheler KR. (2002) SAGE identification of gene transcripts with profiles unique to pluripotent mouse R1 embryonic stem cells. Genomics 79: 169-76 [PMID:11829487]

4. Anselmi L, Lakhter A, Hirano AA, Tonini M and Sternini C. (2005) Expression of galanin receptor messenger RNAs in different regions of the rat gastrointestinal tract. Peptides 26: 8159 [PMID:15808911]

5. Anselmi L, Stella Jr SL, Brecha NC and Sternini C. (2009) Galanin inhibition of voltagedependent $\mathrm{Ca}(2+)$ influx in rat cultured myenteric neurons is mediated by galanin receptor $1 . \mathrm{J}$ Neurosci Res 87: 1107-14 [PMID:19006083]

6. Anselmi L, Stella Jr SL, Lakhter A, Hirano A, Tonini M and Sternini C. (2005) Galanin receptors in the rat gastrointestinal tract. Neuropeptides 39: 349-52 [PMID:16044511]

7. Ash BL, Zanatta SD, Williams SJ, Lawrence AJ and Djouma E. (2011) The galanin-3 receptor antagonist, SNAP 37889, reduces operant responding for ethanol in alcohol-preferring rats. Regul Pept 166: 59-67 [PMID:20736033]

8. Badie-Mahdavi H, Lu X, Behrens MM and Bartfai T. (2005) Role of galanin receptor 1 and galanin receptor 2 activation in synaptic plasticity associated with $3^{\prime}, 5^{\prime}$-cyclic AMP response element-binding protein phosphorylation in the dentate gyrus: studies with a galanin receptor 2 agonist and galanin receptor 1 knockout mice. Neuroscience 133: 591-604 [PMID:15885916]

9. Bailey KR, Pavlova MN, Rohde AD, Hohmann JG and Crawley JN. (2007) Galanin receptor subtype 2 (GalR2) null mutant mice display an anxiogenic-like phenotype specific to the elevated plus-maze. Pharmacol Biochem Behav 86: 8-20 [PMID:17257664]

10. Bajo M, Madamba SG, Lu X, Sharkey LM, Bartfai T and Siggins GR. (2012) Receptor subtypedependent galanin actions on gamma-aminobutyric acidergic neurotransmission and ethanol responses in the central amygdala. Addict Biol 17: 694-705 [PMID:21955024]

11. Barreto SG, Bazargan M, Zotti M, Hussey DJ, Sukocheva OA, Peiris H, Leong M, Keating DJ, Schloithe AC and Carati CJ et al.. (2011) Galanin receptor 3--a potential target for acute pancreatitis therapy. Neurogastroenterol Motil 23: e141-51 [PMID:21303427]

12. Bartfai T, Bedecs K, Land T, Langel U, Bertorelli R, Girotti P, Consolo S, Xu XJ, WiesenfeldHallin Z and Nilsson S. (1991) M-15: high-affinity chimeric peptide that blocks the neuronal actions of galanin in the hippocampus, locus coeruleus, and spinal cord. Proc Natl Acad Sci USA 88: 10961-5 [PMID:1720557]

13. Bartfai T, Langel U, Bedecs K, Andell S, Land T, Gregersen S, Ahrén B, Girotti P, Consolo S and Corwin R. (1993) Galanin-receptor ligand M40 peptide distinguishes between putative galaninreceptor subtypes. Proc Natl Acad Sci USA 90: 11287-91 [PMID:7504301]

14. Bartfai T, Lu X, Badie-Mahdavi H, Barr AM, Mazarati A, Hua XY, Yaksh T, Haberhauer G, Ceide SC and Trembleau L et al.. (2004) Galmic, a nonpeptide galanin receptor agonist, affects behaviors in seizure, pain, and forced-swim tests. Proc Natl Acad Sci USA 101: 10470-5 [PMID:15240875]

15. Belfer I, Hipp H, Bollettino A, McKnight C, Evans C, Virkkunen M, Albaugh B, Max MB, Goldman D and Enoch MA. (2007) Alcoholism is associated with GALR3 but not two other galanin receptor genes. Genes Brain Behav 6: 473-81 [PMID:17083333]

16. Belloni AS, Malendowicz LK, Rucinski M, Guidolin D and Nussdorfer GG. (2007) Galanin stimulates cortisol secretion from human adrenocortical cells through the activation of galanin receptor subtype 1 coupled to the adenylate cyclase-dependent signaling cascade. Int J Mol Med 20: 859-64 [PMID:17982695]

17. Beran RG and Pachlatko C. (1997) Final report of the ILAE Commission on Economic Aspects of Epilepsy, 1994-1997. International League Against Epilepsy. Epilepsia 38: 1359-62 [PMID:9578534]

18. Berger A, Lang R, Moritz K, Santic R, Hermann A, Sperl W and Kofler B. (2004) Galanin receptor subtype GalR2 mediates apoptosis in SH-SY5Y neuroblastoma cells. Endocrinology 145: 500-7 [PMID:14592962]

19. Berger A, Santic R, Almer D, Hauser-Kronberger C, Huemer M, Humpel C, Stockhammer G, Sperl W and Kofler B. (2003) Galanin and galanin receptors in human gliomas. Acta Neuropathol 105: 555-60 [PMID:12734662]

20. Berger A, Tuechler C, Almer D, Kogner P, Ratschek M, Kerbl R, Iismaa TP, Jones N, Sperl W and Kofler B. (2002) Elevated expression of galanin receptors in childhood neuroblastic tumors. Neuroendocrinology 75: 130-8 [PMID:11867941]

21. Bersani M, Johnsen AH, Højrup P, Dunning BE, Andreasen JJ and Holst JJ. (1991) Human galanin: primary structure and identification of two molecular forms. FEBS Lett 283: 189-94 [PMID:1710578]

22. Bersani M, Thim L, Rasmussen TN and Holst JJ. (1991) Galanin and galanin extended at the Nterminus with seven and nine amino acids are produced in and secreted from the porcine 
adrenal medulla in almost equal amounts. Endocrinology 129: 2693-8 [PMID:1718731]

23. Blakeman KH, Hao JX, Xu XJ, Jacoby AS, Shine J, Crawley JN, Iismaa T and Wiesenfeld-Hallin Z. (2003) Hyperalgesia and increased neuropathic pain-like response in mice lacking galanin receptor 1 receptors. Neuroscience 117: 221-7 [PMID:12605908]

24. Bloomquist BT, Beauchamp MR, Zhelnin L, Brown SE, Gore-Willse AR, Gregor P and Cornfield LJ. (1998) Cloning and expression of the human galanin receptor GalR2. Biochem Biophys Res Commun 243: 474-9 [PMID:9480833]

25. Borowsky B, Walker MW, Huang LY, Jones KA, Smith KE, Bard J, Branchek TA and Gerald C. (1998) Cloning and characterization of the human galanin GALR2 receptor. Peptides 19: 177181 [PMID:9880084]

26. Borroto-Escuela DO, Narvaez M, Marcellino D, Parrado C, Narvaez JA, Tarakanov AO, Agnati LF, Díaz-Cabiale Z and Fuxe K. (2010) Galanin receptor-1 modulates 5-hydroxtryptamine-1A signaling via heterodimerization. Biochem Biophys Res Commun 393: 767-72 [PMID:20171159]

27. Boughton CK, Patterson M, Bewick GA, Tadross JA, Gardiner JV, Beale KE, Chaudery F, Hunter G, Busbridge M and Leavy EM et al.. (2010) Alarin stimulates food intake and gonadotrophin release in male rats. Br J Pharmacol 161: 601-13 [PMID:20880399]

28. Bovell DL, Holub BS, Odusanwo O, Brodowicz B, Rauch I, Kofler B and Lang R. (2013) Galanin is a modulator of eccrine sweat gland secretion. Exp Dermatol 22: 141-3 [PMID:23278944]

29. Brumovsky P, Mennicken F, O'donnell D and Hökfelt T. (2006) Differential distribution and regulation of galanin receptors- 1 and -2 in the rat lumbar spinal cord. Brain Res 1085: 111-20 [PMID:16626647]

30. Bulaj G, Green BR, Lee HK, Robertson CR, White K, Zhang L, Sochanska M, Flynn SP, Scholl EA and Pruess TH et al.. (2008) Design, synthesis, and characterization of high-affinity, systemically-active galanin analogues with potent anticonvulsant activities. J Med Chem 51 : 8038-47 [PMID:19053761]

31. Buneman P, Christie G, Davies JA, Dimitrellou R, Harding SD, Pawson AJ, Sharman JL and Wu Y. (2020) Why data citation isn't working, and what to do about it Database 2020 [PMID:32367113]

32. Burazin TC and Gundlach AL. (1998) Inducible galanin and GalR2 receptor system in motor neuron injury and regeneration. $J$ Neurochem 71: 879-82 [PMID:9681481]

33. Burazin TC, Larm JA, Ryan MC and Gundlach AL. (2000) Galanin-R1 and -R2 receptor mRNA expression during the development of rat brain suggests differential subtype involvement in synaptic transmission and plasticity. Eur J Neurosci 12: 2901-17 [PMID:10971633]

34. Burgevin MC, Loquet I, Quarteronet D and Habert-Ortoli E. (1995) Cloning, pharmacological characterization, and anatomical distribution of a rat cDNA encoding for a galanin receptor. $J$ Mol Neurosci 6: 33-41 [PMID:8562318]

35. Cheng S and Yuan CG. (2007) Differential effect of galanin on proliferation of PC12 and B104 cells. Neuroreport 18: 1379-83 [PMID:17762717]

36. Chu M, Mierzwa R, Truumees I, King A, Sapidou E, Barrabee E, Terracciano J, Patel MG and Gullo VP Burrier R et al. (1997) A new fungal metabolite, Sch 202696, with Inhibitory Activity in the Galanin Receptor GALR1 Assay. Tetrahedreon Letters 38: 6111-6114

37. Chung W, Kwabi-Addo B, Ittmann M, Jelinek J, Shen L, Yu Y and Issa JP. (2008) Identification of novel tumor markers in prostate, colon and breast cancer by unbiased methylation profiling. PLOS ONE 3: e2079 [PMID:18446232]

38. Church WB, Jones KA, Kuiper DA, Shine J and Iismaa TP. (2002) Molecular modelling and sitedirected mutagenesis of human GALR1 galanin receptor defines determinants of receptor subtype specificity. Protein Eng 15: 313-23 [PMID:11983932]

39. Cody JD, Hale DE, Brkanac Z, Kaye CI and Leach RJ. (1997) Growth hormone insufficiency associated with haploinsufficiency at 18q23. Am J Med Genet 71: 420-5 [PMID:9286448]

40. Counts SE, Chen EY, Che S, Ikonomovic MD, Wuu J, Ginsberg SD, Dekosky ST and Mufson EJ. (2006) Galanin fiber hypertrophy within the cholinergic nucleus basalis during the progression of Alzheimer's disease. Dement Geriatr Cogn Disord 21: 205-14 [PMID:16410678]

41. Counts SE, McGuire SO, Sortwell CE, Crawley JN, Collier TJ and Mufson EJ. (2002) Galanin inhibits tyrosine hydroxylase expression in midbrain dopaminergic neurons. J Neurochem 83: 442-51 [PMID:12423254]

42. Crawley JN. (1999) The role of galanin in feeding behavior. Neuropeptides 33: 369-75 [PMID:10657514]

43. Cunningham MJ, Scarlett JM and Steiner RA. (2002) Cloning and distribution of galanin-like peptide mRNA in the hypothalamus and pituitary of the macaque. Endocrinology 143: 755-63 [PMID:11861493]

44. Cunningham MJ, Shahab M, Grove KL, Scarlett JM, Plant TM, Cameron JL, Smith MS, Clifton DK and Steiner RA. (2004) Galanin-like peptide as a possible link between metabolism and reproduction in the macaque. J Clin Endocrinol Metab 89: 1760-6 [PMID:15070942]

45. Davis TM, McFail-Isom L, Keane E and Williams LD. (1998) Melting of a DNA hairpin without hyperchromism. Biochemistry 37: 6975-8 [PMID:9578584] 
46. Ding X, MacTavish D, Kar S and Jhamandas JH. (2006) Galanin attenuates beta-amyloid (Abeta) toxicity in rat cholinergic basal forebrain neurons. Neurobiol Dis 21: 413-20 [PMID:16246567]

47. Dostal A, Nemeckova J, Gaillyova R, Vranova V, Zezulkova D, Lejska M, Slapak I, Dostalova Z and Kuglik P. (2006) Identification of 2.3-Mb gene locus for congenital aural atresia in 18q22.3 deletion: a case report analyzed by comparative genomic hybridization. Otol Neurotol 27: 42732 [PMID:16639285]

48. Elliott-Hunt CR, Holmes FE, Hartley DM, Perez S, Mufson EJ and Wynick D. (2011) Endogenous galanin protects mouse hippocampal neurons against amyloid toxicity in vitro via activation of galanin receptor-2. J Alzheimers Dis 25: 455-62 [PMID:21471641]

49. Elliott-Hunt CR, Marsh B, Bacon A, Pope R, Vanderplank P and Wynick D. (2004) Galanin acts as a neuroprotective factor to the hippocampus. Proc Natl Acad Sci USA 101: 5105-10 [PMID:15041741]

50. Elliott-Hunt CR, Pope RJ, Vanderplank P and Wynick D. (2007) Activation of the galanin receptor 2 (GalR2) protects the hippocampus from neuronal damage. J Neurochem 100: 780-9 [PMID:17263796]

51. Elmes P. (1980) Tardive dyskinesia. Br Med J 280: 255 [PMID:7427106]

52. Evans HF and Shine J. (1991) Human galanin: molecular cloning reveals a unique structure. Endocrinology 129: 1682-4 [PMID:1714839]

53. Fathi Z, Battaglino PM, Iben LG, Li H, Baker E, Zhang D, McGovern R, Mahle CD, Sutherland GR and Iismaa TP et al.. (1998) Molecular characterization, pharmacological properties and chromosomal localization of the human GALR2 galanin receptor. Brain Res Mol Brain Res 58: 156-69 [PMID:9685625]

54. Fathi Z, Cunningham AM, Iben LG, Battaglino PB, Ward SA, Nichol KA, Pine KA, Wang J, Goldstein ME and Iismaa TP et al.. (1997) Cloning, pharmacological characterization and distribution of a novel galanin receptor. Brain Res Mol Brain Res 51: 49-59 [PMID:9427506]

55. Fetissov SO, Jacoby AS, Brumovsky PR, Shine J, Iismaa TP and Hökfelt T. (2003) Altered hippocampal expression of neuropeptides in seizure-prone GALR1 knockout mice. Epilepsia 44: 1022-33 [PMID:12887433]

56. Fitzgerald LW, Patterson JP, Conklin DS, Horlick R and Largent BL. (1998) Pharmacological and biochemical characterization of a recombinant human galanin GALR1 receptor: agonist character of chimeric galanin peptides. J Pharmacol Exp Ther 287: 448-56 [PMID:9808667]

57. Foord SM, Bonner TI, Neubig RR, Rosser EM, Pin JP, Davenport AP, Spedding M and Harmar AJ. (2005) International Union of Pharmacology. XLVI. G protein-coupled receptor list. Pharmacol Rev 57: 279-88 [PMID:15914470]

58. Gold AB, Wileyto EP, Lori A, Conti D, Cubells JF and Lerman C. (2012) Pharmacogenetic association of the galanin receptor (GALR1) SNP rs2717162 with smoking cessation. Neuropsychopharmacology 37: 1683-8 [PMID:22373943]

59. Gottsch ML, Zeng H, Hohmann JG, Weinshenker D, Clifton DK and Steiner RA. (2005) Phenotypic analysis of mice deficient in the type 2 galanin receptor (GALR2). Mol Cell Biol 25: 4804-11 [PMID:15899880]

60. Gresle MM, Butzkueven H, Perreau VM, Jonas A, Xiao J, Thiem S, Holmes FE, Doherty W, Soo PY and Binder MD et al.. (2015) Galanin is an autocrine myelin and oligodendrocyte trophic signal induced by leukemia inhibitory factor. Glia 63: 1005-20 [PMID:25639936]

61. Gu ZF, Pradhan TK, Coy DH and Jensen RT. (1995) Interaction of galanin fragments with galanin receptors on isolated smooth muscle cells from guinea pig stomach: identification of a novel galanin receptor subtype. J Pharmacol Exp Ther 272: 371-8 [PMID:7529309]

62. Guerrini S, Raybould HE, Anselmi L, Agazzi A, Cervio E, Reeve Jr JR, Tonini M and Sternini C. (2004) Role of galanin receptor 1 in gastric motility in rat. Neurogastroenterol Motil 16: 429-38 [PMID:15305998]

63. Gundlach AL. (2002) Galanin/GALP and galanin receptors: role in central control of feeding, body weight/obesity and reproduction? Eur J Pharmacol 440: 255-68 [PMID:12007540]

64. Gundlach AL and Burazin TC. (1998) Galanin-galanin receptor systems in the hypothalamic paraventricular and supraoptic nuclei. Some recent findings and future challenges. Ann $N Y$ Acad Sci 863: 241-51 [PMID:9928175]

65. Gunn SR, Mohammed M, Reveles XT, Viskochil DH, Palumbos JC, Johnson-Pais TL, Hale DE, Lancaster JL, Hardies LJ and Boespflug-Tanguy O et al.. (2003) Molecular characterization of a patient with central nervous system dysmyelination and cryptic unbalanced translocation between chromosomes 4q and 18q. Am J Med Genet A 120A: 127-35 [PMID:12794705]

66. Gustafson EL, Smith KE, Durkin MM, Gerald C and Branchek TA. (1996) Distribution of a rat galanin receptor mRNA in rat brain. Neuroreport 7: 953-7 [PMID:8724681]

67. Habert-Ortoli E, Amiranoff B, Loquet I, Laburthe M and Mayaux JF. (1994) Molecular cloning of a functional human galanin receptor. Proc Natl Acad Sci USA 91: 9780-3 [PMID:7524088]

68. Hawes JJ, Narasimhaiah R and Picciotto MR. (2006) Galanin and galanin-like peptide modulate neurite outgrowth via protein kinase C-mediated activation of extracellular signal-related kinase. Eur J Neurosci 23: 2937-46 [PMID:16819983] 
69. Hawes JJ and Picciotto MR. (2004) Characterization of GalR1, GalR2, and GalR3 immunoreactivity in catecholaminergic nuclei of the mouse brain. J Comp Neurol 479: 410-23 [PMID:15514977]

70. Henson BS, Neubig RR, Jang I, Ogawa T, Zhang Z, Carey TE and D'Silva NJ. (2005) Galanin receptor 1 has anti-proliferative effects in oral squamous cell carcinoma. J Biol Chem 280: 22564-71 [PMID:15767248]

71. Hobson SA, Holmes FE, Kerr NC, Pope RJ and Wynick D. (2006) Mice deficient for galanin receptor 2 have decreased neurite outgrowth from adult sensory neurons and impaired pain-like behaviour. J Neurochem 99: 1000-10 [PMID:17076662]

72. Hohmann JG, Juréus A, Teklemichael DN, Matsumoto AM, Clifton DK and Steiner RA. (2003) Distribution and regulation of galanin receptor 1 messenger RNA in the forebrain of wild type and galanin-transgenic mice. Neuroscience 117: 105-17 [PMID:12605897]

73. Holmes A, Kinney JW, Wrenn CC, Li Q, Yang RJ, Ma L, Vishwanath J, Saavedra MC, Innerfield CE and Jacoby AS et al.. (2003) Galanin GAL-R1 receptor null mutant mice display increased anxiety-like behavior specific to the elevated plus-maze. Neuropsychopharmacology 28: 1031-44 [PMID:12700679]

74. Holmes A, Li Q, Koenig EA, Gold E, Stephenson D, Yang RJ, Dreiling J, Sullivan T and Crawley JN. (2005) Phenotypic assessment of galanin overexpressing and galanin receptor R1 knockout mice in the tail suspension test for depression-related behavior. Psychopharmacology (Berl.) 178: 276-85 [PMID:15365683]

75. Howard AD, Tan C, Shiao LL, Palyha OC, McKee KK, Weinberg DH, Feighner SD, Cascieri MA, Smith RG and Van Der Ploeg LH et al.. (1997) Molecular cloning and characterization of a new receptor for galanin. FEBS Lett 405: 285-90 [PMID:9108306]

76. Hua XY, Hayes CS, Hofer A, Fitzsimmons B, Kilk K, Langel U, Bartfai T and Yaksh TL. (2004) Galanin acts at GalR1 receptors in spinal antinociception: synergy with morphine and AP-5. $J$ Pharmacol Exp Ther 308: 574-82 [PMID:14610237]

77. Hulse RP, Donaldson LF and Wynick D. (2012) Differential roles of galanin on mechanical and cooling responses at the primary afferent nociceptor. Mol Pain 8: 41 [PMID:22672616]

78. Hökfelt T and Tatemoto K. (2010) Galanin: a multitalented neuropeptide. EXS 102: 1-5 [PMID:21299057]

79. Jackson KJ, Chen X, Miles MF, Harenza J and Damaj MI. (2011) The neuropeptide galanin and variants in the GalR1 gene are associated with nicotine dependence. Neuropsychopharmacology 36: 2339-48 [PMID:21796100]

80. Jacoby AS, Hort YJ, Constantinescu G, Shine J and Iismaa TP. (2002) Critical role for GALR1 galanin receptor in galanin regulation of neuroendocrine function and seizure activity. Brain Res Mol Brain Res 107: 195-200 [PMID:12487125]

81. Jacoby AS, Webb GC, Liu ML, Kofler B, Hort YJ, Fathi Z, Bottema CD, Shine J and Iismaa TP. (1997) Structural organization of the mouse and human GALR1 galanin receptor genes (Galnr and GALNR) and chromosomal localization of the mouse gene. Genomics 45: 496-508 [PMID:9367674]

82. Jimenez-Andrade JM, Lundström L, Sollenberg UE, Langel U, Castañeda-Hernandez G and Carlton SM. (2006) Activation of peripheral galanin receptors: differential effects on nociception. Pharmacol Biochem Behav 85: 273-80 [PMID:16996122]

83. Jimenez-Andrade JM, Zhou S, Du J, Yamani A, Grady JJ, Castañeda-Hernandez G and Carlton SM. (2004) Pro-nociceptive role of peripheral galanin in inflammatory pain. Pain 110: 10-21 [PMID:15275747]

84. Juréus A, Cunningham MJ, Li D, Johnson LL, Krasnow SM, Teklemichael DN, Clifton DK and Steiner RA. (2001) Distribution and regulation of galanin-like peptide (GALP) in the hypothalamus of the mouse. Endocrinology 142: 5140-4 [PMID:11713207]

85. Kai A, Ono K, Kawano H, Honda E, Nakanishi O and Inenaga K. (2006) Galanin inhibits neural activity in the subfornical organ in rat slice preparation. Neuroscience 143: 769-77 [PMID:17027169]

86. Kanazawa T, Iwashita T, Kommareddi P, Nair T, Misawa K, Misawa Y, Ueda Y, Tono T and Carey TE. (2007) Galanin and galanin receptor type 1 suppress proliferation in squamous carcinoma cells: activation of the extracellular signal regulated kinase pathway and induction of cyclindependent kinase inhibitors. Oncogene 26: 5762-71 [PMID:17384686]

87. Karlsson RM and Holmes A. (2006) Galanin as a modulator of anxiety and depression and a therapeutic target for affective disease. Amino Acids 31: 231-9 [PMID:16733616]

88. Kerekes N, Mennicken F, O'Donnell D, Hökfelt T and Hill RH. (2003) Galanin increases membrane excitability and enhances $\mathrm{Ca}(2+)$ currents in adult, acutely dissociated dorsal root ganglion neurons. Eur J Neurosci 18: 2957-66 [PMID:14656291]

89. Kim DK, Yun S, Son GH, Hwang JI, Park CR, Kim JI, Kim K, Vaudry H and Seong JY. (2014) Coevolution of the spexin/galanin/kisspeptin family: Spexin activates galanin receptor type II and III. Endocrinology 155: 1864-73 [PMID:24517231]

90. Kinney JW, Starosta G, Holmes A, Wrenn CC, Yang RJ, Harris AP, Long KC and Crawley JN. 
(2002) Deficits in trace cued fear conditioning in galanin-treated rats and galaninoverexpressing transgenic mice. Learn Mem 9: 178-90 [PMID:12177231]

91. Kolakowski Jr LF, O'Neill GP, Howard AD, Broussard SR, Sullivan KA, Feighner SD, Sawzdargo M, Nguyen T, Kargman S and Shiao LL et al.. (1998) Molecular characterization and expression of cloned human galanin receptors GALR2 and GALR3. J Neurochem 71: 2239-51 [PMID:9832121]

92. Kong S, Lorenzana A, Deng Q, McNeill TH and Schauwecker PE. (2008) Variation in Galr1 expression determines susceptibility to exocitotoxin-induced cell death in mice. Genes Brain Behav 7: 587-98 [PMID:18363852]

93. Konkel MJ, Lagu B, Boteju LW, Jimenez H, Noble S, Walker MW, Chandrasena G, Blackburn TP, Nikam SS and Wright JL et al.. (2006) 3-arylimino-2-indolones are potent and selective galanin GAL3 receptor antagonists. J Med Chem 49: 3757-8 [PMID:16789730]

94. Konkel MJ, Packiarajan M, Chen H, Topiwala UP, Jimenez H, Talisman IJ, Coate H and Walker MW. (2006) Amino substituted analogs of 1-phenyl-3-phenylimino-2-indolones with potent galanin Gal3 receptor binding affinity and improved solubility. Bioorg Med Chem Lett 16: 39504 [PMID:16730981]

95. Konkel and Michael et al.. (2004) 3-Imino-2-indolones for the treatment of depression and/or anxiety. Patent number: US20040082615.

96. Kuteeva E, Wardi T, Lundström L, Sollenberg U, Langel U, Hökfelt T and Ogren SO. (2008) Differential role of galanin receptors in the regulation of depression-like behavior and monoamine/stress-related genes at the cell body level. Neuropsychopharmacology 33: 2573-85 [PMID:18172432]

97. Landry M, Bouali-Benazzouz R, André C, Shi TJ, Léger C, Nagy F and Hökfelt T. (2006) Galanin receptor 1 is expressed in a subpopulation of glutamatergic interneurons in the dorsal horn of the rat spinal cord. J Comp Neurol 499: 391-403 [PMID:16998907]

98. Landry M, Roche D, Vila-Porcile E and Calas A. (2000) Effects of centrally administered galanin (1-16) on galanin expression in the rat hypothalamus. Peptides 21: 1725-33 [PMID:11090928]

99. Lang R, Berger A, Santic R, Geisberger R, Hermann A, Herzog H and Kofler B. (2005) Pharmacological and functional characterization of galanin-like peptide fragments as potent galanin receptor agonists. Neuropeptides 39: 179-84 [PMID:15944009]

100. Lang R, Gundlach AL, Holmes FE, Hobson SA, Wynick D, Hökfelt T and Kofler B. (2015) Physiology, signaling, and pharmacology of galanin peptides and receptors: three decades of emerging diversity. Pharmacol Rev 67: 118-75 [PMID:25428932]

101. Lang R, Gundlach AL and Kofler B. (2007) The galanin peptide family: receptor pharmacology, pleiotropic biological actions, and implications in health and disease. Pharmacol Ther 115: 177207 [PMID:17604107]

102. Langel U, Pooga M, Kairane C, Zilmer M and Bartfai T. (1996) A galanin-mastoparan chimeric peptide activates the $\mathrm{Na}+, \mathrm{K}(+)$-ATPase and reverses its inhibition by ouabain. Regul Pept 62: 47-52 [PMID:8738882]

103. Lassiter RN, Dude CM, Reynolds SB, Winters NI, Baker CV and Stark MR. (2007) Canonical Wnt signaling is required for ophthalmic trigeminal placode cell fate determination and maintenance. Dev Biol 308: 392-406 [PMID:17604017]

104. Le Maître E, Barde SS, Palkovits M, Diaz-Heijtz R and Hökfelt TG. (2013) Distinct features of neurotransmitter systems in the human brain with focus on the galanin system in locus coeruleus and dorsal raphe. Proc Natl Acad Sci USA 110: E536-45 [PMID:23341594]

105. Le Maître TW, Xia S, Le Maitre E, Dun XP, Lu J, Theodorsson E, Ogren SO, Hökfelt T and Xu ZQ. (2011) Galanin receptor 2 overexpressing mice display an antidepressive-like phenotype: possible involvement of the subiculum. Neuroscience 190: 270-88 [PMID:21672612]

106. Lee SK, Arbini AA and Galloway MT. (2001) Angioleiomyoma of the patellar tendon sheath. Case report. Am J Knee Surg 14: 178-80 [PMID:11491429]

107. Lee YN, Reyes-Alcaraz A, Yun S, Lee CS, Hwang JI and Seong JY. (2020) Exploring the molecular structures that confer ligand selectivity for galanin type II and III receptors. PLoS One 15: e0230872 [PMID:32231393]

108. Leibowitz SF and Kim T. (1992) Impact of a galanin antagonist on exogenous galanin and natural patterns of fat ingestion. Brain Res 599: 148-52 [PMID:1283559]

109. Li J, Zhang JJ, Xu SL and Yu LC. (2012) Antinociceptive effects induced by injection of the galanin receptor 1 agonist M617 into central nucleus of amygdala in rats. Neurosci Lett 526: 45-8 [PMID:22884928]

110. Liu HX, Brumovsky P, Schmidt R, Brown W, Payza K, Hodzic L, Pou C, Godbout C and Hökfelt T. (2001) Receptor subtype-specific pronociceptive and analgesic actions of galanin in the spinal cord: selective actions via GalR1 and GalR2 receptors. Proc Natl Acad Sci USA 98: 9960-4 [PMID:11481429]

111. Liu HX and Hökfelt T. (2002) The participation of galanin in pain processing at the spinal level. Trends Pharmacol Sci 23: 468-74 [PMID:12368071]

112. Lori A, Tang Y, O'Malley S, Picciotto MR, Wu R, Conneely KN and Cubells JF. (2011) The galanin 
receptor 1 gene associates with tobacco craving in smokers seeking cessation treatment. Neuropsychopharmacology 36: 1412-20 [PMID:21430647]

113. Lorimer DD and Benya RV. (1996) Cloning and quantification of galanin-1 receptor expression by mucosal cells lining the human gastrointestinal tract. Biochem Biophys Res Commun 222: 379-85 [PMID:8670213]

114. Louridas M, Letourneau S, Lautatzis ME and Vrontakis M. (2009) Galanin is highly expressed in bone marrow mesenchymal stem cells and facilitates migration of cells both in vitro and in vivo. Biochem Biophys Res Commun 390: 867-71 [PMID:19840773]

115. Lu X, Lundström L and Bartfai T. (2005) Galanin (2-11) binds to GalR3 in transfected cell lines: limitations for pharmacological definition of receptor subtypes. Neuropeptides 39: 165-7 [PMID:15944007]

116. Lu X, Lundström L, Langel U and Bartfai T. (2005) Galanin receptor ligands. Neuropeptides 39: 143-6 [PMID:15944002]

117. Lu X, Roberts E, Xia F, Sanchez-Alavez M, Liu T, Baldwin R, Wu S, Chang J, Wasterlain CG and Bartfai T. (2010) GalR2-positive allosteric modulator exhibits anticonvulsant effects in animal models. Proc Natl Acad Sci USA 107: 15229-34 [PMID:20660766]

118. Lu X, Ross B, Sanchez-Alavez M, Zorrilla EP and Bartfai T. (2008) Phenotypic analysis of GalR2 knockout mice in anxiety- and depression-related behavioral tests. Neuropeptides 42: 387-97 [PMID:18554714]

119. Lundkvist J, Land T, Kahl U, Bedecs K and Bartfai T. (1995) cDNA sequence, ligand biding, and regulation of galanin/GMAP in mouse brain. Neurosci Lett 200: 121-4 [PMID:8614559]

120. Lundström L, Sollenberg U, Brewer A, Kouya PF, Zheng K, Xu X, Sheng X, Robinson JK, Wiesenfeld-Hallin Z and Xu Z et al. (2005) A Galanin Receptor Subtype 1 Specific Agonist. International Journal of Peptide Research and Therapeutics, 11: 17-27

121. Ma X, Tong YG, Schmidt R, Brown W, Payza K, Hodzic L, Pou C, Godbout C, Hökfelt T and Xu ZQ. (2001) Effects of galanin receptor agonists on locus coeruleus neurons. Brain Res 919: 16974 [PMID:11689176]

122. Mahoney SA, Hosking R, Farrant S, Holmes FE, Jacoby AS, Shine J, Iismaa TP, Scott MK, Schmidt R and Wynick D. (2003) The second galanin receptor GalR2 plays a key role in neurite outgrowth from adult sensory neurons. J Neurosci 23: 416-21 [PMID:12533601]

123. Malkmus S, Lu X, Bartfai T, Yaksh TL and Hua XY. (2005) Increased hyperalgesia after tissue injury and faster recovery of allodynia after nerve injury in the GalR1 knockout mice. Neuropeptides 39: 217-21 [PMID:15944015]

124. Margarit E, Morales C, Rodríguez-Revenga L, Monné R, Badenas C, Soler A, Clusellas N, Mademont I and Sánchez A. (2012) Familial 4.8 MB deletion on 18q23 associated with growth hormone insufficiency and phenotypic variability. Am J Med Genet A 158A: 611-6 [PMID:22302430]

125. Mazarati A and Lu X. (2005) Regulation of limbic status epilepticus by hippocampal galanin type 1 and type 2 receptors. Neuropeptides 39: 277-80 [PMID:15944022]

126. Mazarati A, Lu X, Kilk K, Langel U, Wasterlain C and Bartfai T. (2004) Galanin type 2 receptors regulate neuronal survival, susceptibility to seizures and seizure-induced neurogenesis in the dentate gyrus. Eur J Neurosci 19: 3235-44 [PMID:15217380]

127. Mazarati A, Lu X, Shinmei S, Badie-Mahdavi H and Bartfai T. (2004) Patterns of seizures, hippocampal injury and neurogenesis in three models of status epilepticus in galanin receptor type 1 (GalR1) knockout mice. Neuroscience 128: 431-41 [PMID:15350653]

128. Mazarati A, Lundström L, Sollenberg U, Shin D, Langel U and Sankar R. (2006) Regulation of kindling epileptogenesis by hippocampal galanin type 1 and type 2 receptors: The effects of subtype-selective agonists and the role of G-protein-mediated signaling. J Pharmacol Exp Ther 318: 700-8 [PMID:16699066]

129. Mazarati AM, Baldwin RA, Shinmei S and Sankar R. (2005) In vivo interaction between serotonin and galanin receptors types 1 and 2 in the dorsal raphe: implication for limbic seizures. J Neurochem 95: 1495-503 [PMID:16219029]

130. McColl CD, Jacoby AS, Shine J, Iismaa TP and Bekkers JM. (2006) Galanin receptor-1 knockout mice exhibit spontaneous epilepsy, abnormal EEGs and altered inhibition in the hippocampus. Neuropharmacology 50: 209-18 [PMID:16243364]

131. McDonald AC, Schuijers JA, Gundlach AL and Grills BL. (2007) Galanin treatment offsets the inhibition of bone formation and downregulates the increase in mouse calvarial expression of TNFalpha and GalR2 mRNA induced by chronic daily injections of an injurious vehicle. Bone 40: 895-903 [PMID:17157570]

132. McDonald MP, Gleason TC, Robinson JK and Crawley JN. (1998) Galanin inhibits performance on rodent memory tasks. Ann N Y Acad Sci 863: 305-22 [PMID:9928180]

133. Melander T, Köhler C, Nilsson S, Hökfelt T, Brodin E, Theodorsson E and Bartfai T. (1988) Autoradiographic quantitation and anatomical mapping of 125I-galanin binding sites in the rat central nervous system. J Chem Neuroanat 1: 213-33 [PMID:2477035]

134. Mennicken F, Hoffert C, Pelletier M, Ahmad S and O'Donnell D. (2002) Restricted distribution of 
galanin receptor 3 (GalR3) mRNA in the adult rat central nervous system. J Chem Neuroanat 24: 257-68 [PMID:12406501]

135. Misawa K, Ueda Y, Kanazawa T, Misawa Y, Jang I, Brenner JC, Ogawa T, Takebayashi S, Grenman RA and Herman JG et al.. (2008) Epigenetic inactivation of galanin receptor 1 in head and neck cancer. Clin Cancer Res 14: 7604-13 [PMID:19047085]

136. Mitsukawa K, Lu X and Bartfai T. (2009) Bidirectional regulation of stress responses by galanin in mice: involvement of galanin receptor subtype 1. Neuroscience 160: 837-46 [PMID:19272414]

137. Nancarrow DJ, Handoko HY, Smithers BM, Gotley DC, Drew PA, Watson DI, Clouston AD, Hayward NK and Whiteman DC. (2008) Genome-wide copy number analysis in esophageal adenocarcinoma using high-density single-nucleotide polymorphism arrays. Cancer Res 68 : 4163-72 [PMID:18519675]

138. NCBI. LPHN2 - Ovarian cancer and depression.

139. Nicholl J, Kofler B, Sutherland GR, Shine J and Iismaa TP. (1995) Assignment of the gene encoding human galanin receptor (GALNR) to 18q23 by in situ hybridization. Genomics 30: 62930 [PMID:8825658]

140. Niiro N, Nishimura J, Hirano K, Nakano H and Kanaide H. (1998) Mechanisms of galanininduced contraction in the rat myometrium. Br J Pharmacol 124: 1623-32 [PMID:9756377]

141. O'Donnell D, Ahmad S, Wahlestedt C and Walker P. (1999) Expression of the novel galanin receptor subtype GALR2 in the adult rat CNS: distinct distribution from GALR1. J Comp Neurol 409: 469-81 [PMID:10379831]

142. Ohtaki T, Kumano S, Ishibashi Y, Ogi K, Matsui H, Harada M, Kitada C, Kurokawa T, Onda H and Fujino M. (1999) Isolation and cDNA cloning of a novel galanin-like peptide (GALP) from porcine hypothalamus. J Biol Chem 274: 37041-5 [PMID:10601261]

143. Page AJ, Slattery JA, Brierley SM, Jacoby AS and Blackshaw LA. (2007) Involvement of galanin receptors 1 and 2 in the modulation of mouse vagal afferent mechanosensitivity. $J$ Physiol (Lond.) 583: 675-84 [PMID:17627995]

144. Pang L, Hashemi T, Lee HJ, Maguire M, Graziano MP, Bayne M, Hawes B, Wong G and Wang S. (1998) The mouse GalR2 galanin receptor: genomic organization, cDNA cloning, and functional characterization. J Neurochem 71: 2252-9 [PMID:9832122]

145. Parker EM, Izzarelli DG, Nowak HP, Mahle CD, Iben LG, Wang J and Goldstein ME. (1995) Cloning and characterization of the rat GALR1 galanin receptor from Rin14B insulinoma cells. Brain Res Mol Brain Res 34: 179-89 [PMID:8750821]

146. Perel Y, Amrein L, Dobremez E, Rivel J, Daniel JY and Landry M. (2002) Galanin and galanin receptor expression in neuroblastic tumours: correlation with their differentiation status. $\mathrm{Br} \mathrm{J}$ Cancer 86: 117-22 [PMID:11857022]

147. Pirondi S, Fernandez M, Schmidt R, Hökfelt T, Giardino L and Calzà L. (2005) The galanin-R2 agonist AR-M1896 reduces glutamate toxicity in primary neural hippocampal cells. J Neurochem 95: 821-33 [PMID:16248891]

148. Potter EK and Smith-White MA. (2005) Galanin modulates cholinergic neurotransmission in the heart. Neuropeptides 39: 345-8 [PMID:15944033]

149. Poulain P, Decrocq N and Mitchell V. (2003) Direct inhibitory action of galanin on hypothalamic arcuate nucleus neurones expressing galanin receptor Gal-r1 mRNA. Neuroendocrinology 78: 105-17 [PMID:12915763]

150. Pristov JB, Mitrović A and Spasojević I. (2011) A comparative study of antioxidative activities of cell-wall polysaccharides. Carbohydr Res 346: 2255-9 [PMID:21880306]

151. Reyes-Alcaraz A, Lee YN, Son GH, Kim NH, Kim DK, Yun S, Kim DH, Hwang JI and Seong JY. (2016) Development of Spexin-based Human Galanin Receptor Type II-Specific Agonists with Increased Stability in Serum and Anxiolytic Effect in Mice. Sci Rep 6: 21453 [PMID:26907960]

152. Rezaei K, Xu IS, Wu WP, Shi TJ, Soomets U, Land T, Xu XJ, Wiesenfeld-Hallin Z, Hökfelt T and Bartfai $T$ et al.. (2001) Intrathecal administration of PNA targeting galanin receptor reduces galanin-mediated inhibitory effect in the rat spinal cord. Neuroreport 12: 317-20 [PMID:11209942]

153. Robertson CR, Scholl EA, Pruess TH, Green BR, White HS and Bulaj G. (2010) Engineering galanin analogues that discriminate between GalR1 and GalR2 receptor subtypes and exhibit anticonvulsant activity following systemic delivery. J Med Chem 53: 1871-5 [PMID:20121116]

154. Rossmanith WG, Clifton DK and Steiner RA. (1996) Galanin gene expression in hypothalamic GnRH-containing neurons of the rat: a model for autocrine regulation. Horm Metab Res 28: 25766 [PMID:8811325]

155. Runesson J, Saar I, Lundström L, Järv J and Langel U. (2009) A novel GalR2-specific peptide agonist. Neuropeptides 43: 187-92 [PMID:19467704]

156. Saar I, Lahe J, Langel K, Runesson J, Webling K, Järv J, Rytkönen J, Närvänen A, Bartfai T and Kurrikoff $\mathrm{K}$ et al.. (2013) Novel systemically active galanin receptor 2 ligands in depression-like behavior. J Neurochem 127: 114-23 [PMID:23600864]

157. Saar I, Runesson J, Järv J, Kurrikoff K and Langel U. (2013) Novel galanin receptor subtype 
specific ligand in depression like behavior. Neurochem Res 38: 398-404 [PMID:23192661]

158. Saar I, Runesson J, McNamara I, Järv J, Robinson JK and Langel U. (2011) Novel galanin receptor subtype specific ligands in feeding regulation. Neurochem Int 58: 714-20 [PMID:21333705]

159. Saar K, Mahlapuu R, Laidmäe E, Valkna A, Kahl U, Karelson E and Langel U. (2001) Characterisation of a new chimeric ligand for galanin receptors: galanin(1-13)-[D-Trp(32)]neuropeptide Y(25-36)amide. Regul Pept 102: 15-9 [PMID:11600206]

160. Sadegh M, Mirnajafi-Zadeh J, Javan M, Fathollahi Y, Mohammad-Zadeh M, Jahanshahi A and Noorbakhsh SM. (2007) The role of galanin receptors in anticonvulsant effects of low-frequency stimulation in perforant path-kindled rats. Neuroscience 150: 396-403 [PMID:17993248]

161. Sagi VN, Liu T, Lu X, Bartfai T and Roberts E. (2011) Synthesis and biological evaluation of novel pyrimidine derivatives as sub-micromolar affinity ligands of GalR2. Bioorg Med Chem Lett 21: 7210-5 [PMID:22018787]

162. Schmidhuber SM, Rauch I, Kofler B and Brain SD. (2009) Evidence that the modulatory effect of galanin on inflammatory edema formation is mediated by the galanin receptor 3 in the murine microvasculature. J Mol Neurosci 37: 177-81 [PMID:18679831]

163. Schmidhuber SM, Santic R, Tam CW, Bauer JW, Kofler B and Brain SD. (2007) Galanin-like peptides exert potent vasoactive functions in vivo. J Invest Dermatol 127: 716-21 [PMID:17024098]

164. Schwartz N, Temkin P, Jurado S, Lim BK, Heifets BD, Polepalli JS and Malenka RC. (2014) Chronic pain. Decreased motivation during chronic pain requires long-term depression in the nucleus accumbens. Science 345: 535-42 [PMID:25082697]

165. Schött PA, Hökfelt T and Ogren SO. (2000) Galanin and spatial learning in the rat. Evidence for a differential role for galanin in subregions of the hippocampal formation. Neuropharmacology 39: 1386-403 [PMID:10818255]

166. Scott MK, Ross TM, Lee DH, Wang HY, Shank RP, Wild KD, Davis CB, Crooke JJ, Potocki AC and Reitz AB. (2000) 2,3-Dihydro-dithiin and -dithiepine-1,1,4,4-tetroxides: small molecule nonpeptide antagonists of the human galanin hGAL-1 receptor. Bioorg Med Chem 8: 1383-91 [PMID:10896115]

167. Shen PJ, Larm JA and Gundlach AL. (2003) Expression and plasticity of galanin systems in cortical neurons, oligodendrocyte progenitors and proliferative zones in normal brain and after spreading depression. Eur J Neurosci 18: 1362-76 [PMID:14511317]

168. Sherin JE, Elmquist JK, Torrealba F and Saper CB. (1998) Innervation of histaminergic tuberomammillary neurons by GABAergic and galaninergic neurons in the ventrolateral preoptic nucleus of the rat. J Neurosci 18: 4705-21 [PMID:9614245]

169. Shi TJ, Hua XY, Lu X, Malkmus S, Kinney J, Holmberg K, Wirz S, Ceccatelli S, Yaksh T and Bartfai T et al.. (2006) Sensory neuronal phenotype in galanin receptor 2 knockout mice: focus on dorsal root ganglion neurone development and pain behaviour. Eur J Neurosci 23: 627-36 [PMID:16487144]

170. Sillard R, Rökaeus A, Xu Y, Carlquist M, Bergman T, Jörnvall H and Mutt V. (1992) Variant forms of galanin isolated from porcine brain. Peptides 13: 1055-60 [PMID:1283627]

171. Skofitsch G, Sills MA and Jacobowitz DM. (1986) Autoradiographic distribution of 125I-galanin binding sites in the rat central nervous system. Peptides 7: 1029-42 [PMID:2436195]

172. Smith KE, Forray C, Walker MW, Jones KA, Tamm JA, Bard J, Branchek TA, Linemeyer DL and Gerald C. (1997) Expression cloning of a rat hypothalamic galanin receptor coupled to phosphoinositide turnover. J Biol Chem 272: 24612-6 [PMID:9305929]

173. Smith KE, Walker MW, Artymyshyn R, Bard J, Borowsky B, Tamm JA, Yao WJ, Vaysse PJ, Branchek TA and Gerald C et al.. (1998) Cloned human and rat galanin GALR3 receptors. Pharmacology and activation of G-protein inwardly rectifying K+ channels. J Biol Chem $\mathbf{2 7 3}$ : 23321-6 [PMID:9722565]

174. Sollenberg U, Bartfai T and Langel U. (2005) Galnon--a low-molecular weight ligand of the galanin receptors. Neuropeptides 39: 161-3 [PMID:15944006]

175. Sollenberg UE, Lundstrom L, Barfa T and Langel U. (2006) M871- A Novel Peptide Antagonist Selectively Recognising the Galanin Receptor Type 2. Int J Pept Res 12: 115-119

176. Sollenberg UE, Runesson J, Sillard R and Langel U. (2010) Binding of chimeric peptides M617 and M871 to galanin receptor type 3 reveals characteristics of galanin receptor-ligand interaction. Int J Pept Res: 17-22

177. Steininger TL, Gong H, McGinty D and Szymusiak R. (2001) Subregional organization of preoptic area/anterior hypothalamic projections to arousal-related monoaminergic cell groups. $J$ Comp Neurol 429: 638-53 [PMID:11135241]

178. Sten Shi TJ, Zhang X, Holmberg K, Xu ZQ and Hökfelt T. (1997) Expression and regulation of galanin-R2 receptors in rat primary sensory neurons: effect of axotomy and inflammation. Neurosci Lett 237: 57-60 [PMID:9453214]

179. Stevenson L, Allen WL, Turkington R, Jithesh PV, Proutski I, Stewart G, Lenz HJ, Van Schaeybroeck S, Longley DB and Johnston PG. (2012) Identification of galanin and its receptor 
GalR1 as novel determinants of resistance to chemotherapy and potential biomarkers in colorectal cancer. Clin Cancer Res 18: 5412-26 [PMID:22859720]

180. Sugimoto T, Seki N, Shimizu S, Kikkawa N, Tsukada J, Shimada H, Sasaki K, Hanazawa T, Okamoto Y and Hata A. (2009) The galanin signaling cascade is a candidate pathway regulating oncogenesis in human squamous cell carcinoma. Genes Chromosomes Cancer 48: 132-42 [PMID:18973137]

181. Sullivan KA, Shiao LL and Cascieri MA. (1997) Pharmacological characterization and tissue distribution of the human and rat GALR1 receptors. Biochem Biophys Res Commun 233: 823-8 [PMID:9168941]

182. Sutton BS, Langefeld CD, Campbell JK, Haffner SM, Norris JM, Scherzinger AL, Wagenknecht LE and Bowden DW. (2006) Genetic mapping of a 17q chromosomal region linked to obesity phenotypes in the IRAS family study. Int J Obes (Lond.) 30: 1433-41 [PMID:16520807]

183. Swanson CJ, Blackburn TP, Zhang X, Zheng K, Xu ZQ, Hökfelt T, Wolinsky TD, Konkel MJ, Chen $\mathrm{H}$ and Zhong $\mathrm{H}$ et al.. (2005) Anxiolytic- and antidepressant-like profiles of the galanin-3 receptor (Gal3) antagonists SNAP 37889 and SNAP 398299. Proc Natl Acad Sci USA 102: 17489-94 [PMID:16287967]

184. Tofighi R, Joseph B, Xia S, Xu ZQ, Hamberger B, Hökfelt T and Ceccatelli S. (2008) Galanin decreases proliferation of PC12 cells and induces apoptosis via its subtype 2 receptor (GalR2). Proc Natl Acad Sci USA 105: 2717-22 [PMID:18272487]

185. Trejter M, Brelinska R, Warchol JB, Butowska W, Neri G, Rebuffat P, Gottardo L and Malendowicz LK. (2002) Effects of galanin on proliferation and apoptosis of immature rat thymocytes. Int J Mol Med 10: 183-6 [PMID:12119556]

186. Ulman LG, Moriarty M, Potter EK and McCloskey DI. (1993) Galanin antagonist effects on cardiac vagal inhibitory actions of sympathetic stimulation in anaesthetized cats and dogs. $J$ Physiol (Lond.) 464: 491-9 [PMID:7693918]

187. Wang S, Clemmons A, Strader C and Bayne M. (1998) Evidence for hydrophobic interaction between galanin and the GalR1 galanin receptor and GalR1-mediated ligand internalization: fluorescent probing with a fluorescein-galanin. Biochemistry 37: 9528-35 [PMID:9649336]

188. Wang S, Ghibaudi L, Hashemi T, He C, Strader C, Bayne M, Davis H and Hwa JJ. (1998) The GalR2 galanin receptor mediates galanin-induced jejunal contraction, but not feeding behavior, in the rat: differentiation of central and peripheral effects of receptor subtype activation. FEBS Lett 434: 277-82 [PMID:9742938]

189. Wang S, Hashemi T, Fried S, Clemmons AL and Hawes BE. (1998) Differential intracellular signaling of the GalR1 and GalR2 galanin receptor subtypes. Biochemistry 37: 6711-7 [PMID:9578554]

190. Wang S, Hashemi T, He C, Strader C and Bayne M. (1997) Molecular cloning and pharmacological characterization of a new galanin receptor subtype. Mol Pharmacol 52: 337-43 [PMID:9281594]

191. Wang S, He C, Hashemi T and Bayne M. (1997) Cloning and expressional characterization of a novel galanin receptor. Identification of different pharmacophores within galanin for the three galanin receptor subtypes. J Biol Chem 272: 31949-52 [PMID:9405385]

192. Wang S, He C, Maguire MT, Clemmons AL, Burrier RE, Guzzi MF, Strader CD, Parker EM and Bayne ML. (1997) Genomic organization and functional characterization of the mouse GalR1 galanin receptor. FEBS Lett 411: 225-30 [PMID:9271210]

193. Waters SM and Krause JE. (2000) Distribution of galanin-1, -2 and -3 receptor messenger RNAs in central and peripheral rat tissues. Neuroscience 95: 265-71 [PMID:10619483]

194. Wiedmann M, Hagendorff A, Böhm R, Schulz T, Mössner J and Caca K. (2005) Malignant oesophago-pleuro-pericardial fistula in a patient with oesophageal carcinoma. $Z$ Kardiol 94: 4114 [PMID:15940442]

195. Wiesenfeld-Hallin Z, Xu XJ, Crawley JN and Hökfelt T. (2005) Galanin and spinal nociceptive mechanisms: recent results from transgenic and knock-out models. Neuropeptides 39: 207-10 [PMID:15944013]

196. Wiesenfeld-Hallin Z, Xu XJ, Langel U, Bedecs K, Hökfelt T and Bartfai T. (1992) Galaninmediated control of pain: enhanced role after nerve injury. Proc Natl Acad Sci USA 89: 3334-7 [PMID:1373497]

197. Wirz SA, Davis CN, Lu X, Zal T and Bartfai T. (2005) Homodimerization and internalization of galanin type 1 receptor in living CHO cells. Neuropeptides 39: 535-46 [PMID:16242774]

198. Wittau N, Grosse R, Kalkbrenner F, Gohla A, Schultz G and Gudermann T. (2000) The galanin receptor type 2 initiates multiple signaling pathways in small cell lung cancer cells by coupling to G(q), G(i) and G(12) proteins. Oncogene 19: 4199-209 [PMID:10980593]

199. Wraith DC, Pope R, Butzkueven H, Holder H, Vanderplank P, Lowrey P, Day MJ, Gundlach AL, Kilpatrick TJ and Scolding $\mathrm{N}$ et al.. (2009) A role for galanin in human and experimental inflammatory demyelination. Proc Natl Acad Sci USA 106: 15466-71 [PMID:19717462]

200. Wrenn CC, Kinney JW, Marriott LK, Holmes A, Harris AP, Saavedra MC, Starosta G, Innerfield CE, Jacoby AS and Shine J et al.. (2004) Learning and memory performance in mice lacking the 
GAL-R1 subtype of galanin receptor. Eur J Neurosci 19: 1384-96 [PMID:15016096]

201. Wynick D, Smith DM, Ghatei M, Akinsanya K, Bhogal R, Purkiss P, Byfield P, Yanaihara N and Bloom SR. (1993) Characterization of a high-affinity galanin receptor in the rat anterior pituitary: absence of biological effect and reduced membrane binding of the antagonist M15 differentiate it from the brain/gut receptor. Proc Natl Acad Sci USA 90: 4231-5 [PMID:7683428]

202. Xia S, Kjaer S, Zheng K, Hu PS, Bai L, Jia JY, Rigler R, Pramanik A, Xu T and Hökfelt T et al.. (2004) Visualization of a functionally enhanced GFP-tagged galanin R2 receptor in PC12 cells: constitutive and ligand-induced internalization. Proc Natl Acad Sci USA 101: 15207-12 [PMID:15471987]

203. Xia S, Kjaer S, Zheng K, Hu PS, Xu T, Hökfelt T and Xu ZQ. (2005) Constitutive and ligandinduced internalization of EGFP-tagged galanin R2 and Rl receptors in PC12 cells. Neuropeptides 39: 173-8 [PMID:15885774]

204. Xu X, Liu Z, Liu H, Yang X and Li Z. (2012) The effects of galanin on neuropathic pain in streptozotocin-induced diabetic rats. Eur J Pharmacol 680: 28-33 [PMID:22306246]

205. Xu ZQ, Shi TJ, Landry M and Hökfelt T. (1996) Evidence for galanin receptors in primary sensory neurones and effect of axotomy and inflammation. Neuroreport 8: $237-42$ [PMID:9051788]

206. Yang $Y$, Nagano H, Ota H, Morimoto O, Nakamura M, Wada H, Noda T, Damdinsuren B, Marubashi S and Miyamoto A et al.. (2007) Patterns and clinicopathologic features of extrahepatic recurrence of hepatocellular carcinoma after curative resection. Surgery 141: 196202 [PMID:17263976]

207. Yang Y, Zhang Y, Li XH, Li Y, Qian R, Li J and Xu SL. (2015) Involvements of galanin and its receptors in antinociception in nucleus accumbens of rats with inflammatory pain. Neurosci Res 97: 20-5 [PMID:25819845]

208. Zhang L, Klein BD, Metcalf CS, Smith MD, McDougle DR, Lee HK, White HS and Bulaj G. (2013) Incorporation of monodisperse oligoethyleneglycol amino acids into anticonvulsant analogues of galanin and neuropeptide y provides peripherally acting analgesics. Mol Pharm 10: 574-85 [PMID:23259957]

209. Zhang L, Robertson CR, Green BR, Pruess TH, White HS and Bulaj G. (2009) Structural requirements for a lipoamino acid in modulating the anticonvulsant activities of systemically active galanin analogues. J Med Chem 52: 1310-6 [PMID:19199479] 